\title{
Potential phosphorus release from catch crop shoots and roots after freezing-thawing
}

\author{
Jian Liu • Rafa Khalaf • Barbro Ulén • \\ Göran Bergkvist
}

Received: 30 October 2012 / Accepted: 5 April 2013 / Published online: 21 April 2013

(C) The Author(s) 2013. This article is published with open access at Springerlink.com

\begin{abstract}
Background and aims Catch crops used for mitigating nutrient losses to water can release phosphorus $(\mathrm{P})$ when exposed to repeated freezing-thawing cycles (FTCs). This study sought to evaluate potential P losses from shoots and roots of eight catch crops.

Methods Shoots and roots sampled from perennial ryegrass (Lolium perenne L.), cocksfoot (Dactylis glomerata L.), chicory (Cichorium intybus L.), phacelia (Phacelia tanacetifolia L.), red clover (Trifolium pratense L.), white mustard (Sinapis alba L.), oilseed radish (Raphanus sativus var. oleiformis L.) and white radish (R. sativus var. longipinnatus L.) were treated with no freezing, one single FTC, four continuous FTCs and four discontinuous FTCs. All samples were analysed for water-extractable P (WEP), and root samples also for characteristics such as specific root surface area (SSA).

Results Freezing-thawing significantly increased potential P losses from both shoots and roots compared
\end{abstract}

Responsible Editor: Tim Simon George.

J. Liu $(\bowtie) \cdot$ R. Khalaf $\cdot$ B. Ulén

Department of Soil and Environment,

Swedish University of Agricultural Sciences,

Box 7014, 75007 Uppsala, Sweden

e-mail: jian.liu@slu.se

G. Bergkvist

Department of Crop Production Ecology,

Swedish University of Agricultural Sciences,

Box 7043, 75007 Uppsala, Sweden with no freezing. The two radish species and white mustard contained significantly higher concentrations of WEP than the other species, among which chicory and phacelia had the lowest WEP. On average, shoots had $43 \%$ higher WEP than roots. Cumulative P release from shoots and roots was strongly correlated with their total-P content ( $p=0.006$ and $p=0.002$, respectively). Cumulative release of $\mathrm{P}$ from taproots was correlated with SSA $(p=0.03)$.

Conclusions Chicory, and possibly phacelia, appear to be promising catch crops for $\mathrm{P}$.

Keywords Water-extractable phosphorus - Catch crop · Cover crop $\cdot$ Root morphology $\cdot$ Freezing-thawing · Climate change

\section{Introduction}

Agricultural land is the major non-point source of nutrient losses to water bodies and is estimated to contribute roughly $40 \%$ of the total phosphorus (P) loading to Swedish freshwater bodies and the Baltic Sea (Brandt et al. 2008). Phosphorus in the tissues of plants, both aboveground parts and roots, represents a potential source of $\mathrm{P}$ losses to water, in addition to $\mathrm{P}$ bound in the soil and $\mathrm{P}$ added to the soil through fertilisers and animal manure. Phosphorus released from plant tissues is of especially high relevance in conditions with repeated freezing and thawing of plants and soil during winter. Losses of P from shoots 
after frost damage have been reported, for instance, for native prairie vegetation (White 1973), grassland (Uhlen 1989), alfalfa and grasses (Timmons et al. 1970; Roberson et al. 2007), vegetated buffer zones/strips consisting of grasses and other plant species (Räty et al. 2010), and different species of catch/cover crops (Miller et al. 1994; Bechmann et al. 2005; Sturite et al. 2007). However, most of these studies examined only aboveground parts of the plants and few studies have included plant roots damaged by frost (De Baets et al. 2011; Kreyling et al. 2012).

Catch crops are grown in the period between two main crops with the purpose of reducing losses of nutrients, mainly nitrogen $(\mathrm{N})$, from the system. They may be either under-sown in the previous main crop or sown after the main crop is harvested and are generally incorporated into the soil before sowing of the subsequent crop. Such crops are also widely referred to as cover crops when they are grown to protect the soil from erosion (Morgan 2005; Bechmann et al. 2005). Growing catch crops has become common in Sweden and other Scandinavian countries, where government subsidies to promote the practice have been introduced in recent decades (Ulén 1997; Ulén et al. 2007). In some parts of southern Sweden in 2011, catch crops were used on two-thirds of arable land harvested before September and not sown with a winter annual crop (Swedish Board of Agriculture 2012). Perennial ryegrass (Lolium perenne L.) under-sown in cereal crops in the spring is a frequently used catch crop to reduce $\mathrm{N}$ leaching from Swedish agricultural fields during autumn, winter and early spring in years without autumn-sown main crops (Aronsson and Torstensson 1998). There is also great interest in cultivating catch crops with better residual effects for the following main crop. Such catch crops, which generally belong to the family Brassicaceae, e.g. radish (Raphanus sativus L.) and white mustard (Sinapis alba L.), are commonly grown on farms that do not grow related main crops, i.e. oilseed rape (Swedish Board of Agriculture 2012). The Brassica catch crops are generally broadcast a few weeks before harvest of an annual main crop or sown immediately after harvest. Eichler-Löbermann et al. (2008) reported that catch crops can take up 3-6 $\mathrm{kg} \mathrm{P} \mathrm{ha}^{-1}$ in their above-ground parts. Liu et al. (unpublished observations) observed that under very good field growing conditions, the catch crops took up 6-15 $\mathrm{kg} \mathrm{P}^{-1}$ in the whole plant, with $15-70 \%$ of the $\mathrm{P}$ in the roots in dependence on species. A number of studies have demonstrated that catch crops can reduce potential $\mathrm{P}$ losses in surface runoff by preventing soil erosion (e.g. De Baets et al. 2011), but little is reported on their efficiency in reducing $\mathrm{P}$ losses by leaching. Besides the common requirements that the selected catch crops should be easy established, grow fast and take up much $\mathrm{N}$ after the main crop is harvested, the catch crops should also have the smallest possible release of $\mathrm{P}$ after frost damage. Water transport can be very fast through soils and therefore P leached from catch crop tissues should be minimized.

In winter-time, plant cells may burst due to ice crystal formation and frost damage, which leads to a reduced water potential that draws water from adjacent cells (Jones 1992). The damage caused to cells or cell death due to freezing can lead to the release of inter/intra-cellular P from catch crops. The extent of damage and release of $\mathrm{P}$ from plant materials may increase with increasing number of freezing-thawing cycles (FTCs). For example, Bechmann et al. (2005) reported that water-extractable $\mathrm{P}$ (WEP) from shoot biomass of annual ryegrass (Lolium multiflorum L.) increased more than two-fold after eight FTCs compared with a single FTC. In addition, Stier et al. (2003) observed that freezing of turf grasses started with the roots and then progressed to the shoots when the whole plants were exposed to a controlled temperature that was reduced from $0{ }^{\circ} \mathrm{C}$ to $-28^{\circ} \mathrm{C}$. Therefore the $\mathrm{P}$ release pattern may differ between shoots and roots.

There are many deviating opinions on future climate and the rate of increasing air temperature. Furthermore, future climate scenarios are mainly predicted for large-scale areas and not for regional or local scales. However, Henry (2008) and Mellander et al. (2007) have predicted an increasing number and intensity of soil FTCs in Canada and Scandinavia during the next 50 to 100 years. This may especially be the case in regions that currently experience long periods with temperatures below zero, because more fluctuation around $0{ }^{\circ} \mathrm{C}$ can be expected in such areas (Rummukainen 2012). In addition, these cycles may be followed by more or less immediate snowmelt or rain, which may act as an extraction agent on plant and soil materials. On the other hand, decreasing numbers and intensities of FTCs are predicted to occur in Central Europe, together with a warmer climate (Kreyling and Henry 2011).

The main objective of the present study was to evaluate potential $\mathrm{P}$ release from plant materials of 
some species that are used, or can potentially be used, as catch crops, after freezing and thawing of both aboveground plant parts (in this paper referred to as shoots) and roots. Four different combinations of freezing-thawing were chosen to represent extreme components of a winter climate. In addition, the relationship between $\mathrm{P}$ release from the roots and root morphological properties was evaluated. The specific hypotheses tested were that: (1) Concentrations of $\mathrm{P}$ in plant materials and WEP differ between potential catch crop species; (2) more P can be extracted from the biomass after repeated FTCs than after a single FTC; (3) concentrations of WEP are higher in shoots than in roots; (4) and concentrations of WEP in roots are higher in species with large specific root length (SRL, $\mathrm{m} \mathrm{g}^{-1}$ ), specific root surface area (SSA, $\mathrm{dm}^{2} \mathrm{~g}^{-1}$ ) and specific root volume (SRV, $\mathrm{cm}^{3} \mathrm{~g}^{-1}$ ) than in species with small SRL, SSA and SRV.

\section{Materials and methods}

\section{Experimental catch crops}

The eight plant species used were the perennial crops perennial ryegrass (Lolium perenne L. var. Helmer), cocksfoot (Dactylis glomerata L. var. Luxor), chicory (Cichorium intybus L. var. Puna) and red clover (Trifolium pratense L. var. Vivi), and the annual crops phacelia (Phacelia tanacetifolia L.), white mustard (Sinapis alba L. var. Achilles), oilseed radish (Raphanus sativus var. oleiformis 'Adios') and white radish ( $R$. sativus var. longipinnatus 'Structurator'). The two forage grasses, perennial ryegrass and cocksfoot, have fibrous roots. Chicory has a stout taproot with a high dry matter content and can survive exposure to low temperatures (down to $-7{ }^{\circ} \mathrm{C}$ ) for several weeks (Neefs et al. 2000). The forage legume red clover has a deep taproot. Phacelia is an annual herbaceous plant with extensive, fine roots (StiversYoung 1998), and is reported to have high N scavenging ability due to its fast growth and high dry matter production (Gilbert 2003). White mustard, oilseed radish and white radish belong to the Brassicaceae and have a taproot. They also share many common characteristics such as their sensitivity to frost and their fast decomposition. The roots of white radish have better ability to penetrate through dense soil than those of oilseed radish (Chen and Weil 2010).
Greenhouse cultivation

Each of the eight catch crops was sown in triplicate plastic cultivation boxes $(36 \mathrm{~cm} \times 26 \mathrm{~cm} \times 22 \mathrm{~cm})$ that were filled with $17 \mathrm{~L}$ pure dry sand (Sibelco Nordic $\mathrm{AB}$, Mölndal, Sweden) to a depth of $18 \mathrm{~cm}$, in a greenhouse on 16 February 2011. The sand had $90 \%$ of particles with diameter between 0.25 and $1 \mathrm{~mm}$ and a mineral composition of $99 \% \mathrm{SiO}_{2}$, and was saturated with $6 \mathrm{~L}$ tap water. The crops were sown at a rate of 48 seeds per box ( $=$ seed rate of $8 \mathrm{~kg} \mathrm{ha}^{-1}$ for the perennial species and $20 \mathrm{~kg} \mathrm{ha}^{-1}$ for the annual species). In order to distribute the seeds as evenly as possible, each seed was applied to one of 48 equal small rectangles drawn on the soil surface. The seeds were top-dressed with $1.5 \mathrm{~cm}$ dry soil after sowing. The 24 boxes were distributed on a bench in the greenhouse according to a completely randomised design and the soil surface was covered with plastic until the seeds germinated, in order to prevent high evaporative losses.

In addition to natural light, artificial light (Philips MGR 102-400, HPI-T $400 \mathrm{~W}$ ) was supplied for $18 \mathrm{~h}$ during daytime. The temperature was adjusted according to needs at different stages of the experiment; $+15{ }^{\circ} \mathrm{C}$ for the first 5 days after sowing to achieve suitable germination condition for all species, followed by an increase to an average of $+21{ }^{\circ} \mathrm{C}$ to accelerate growth and development of the catch crops, until harvest of white radish and white mustard. Thereafter, the temperature was lowered to $+9{ }^{\circ} \mathrm{C}$ until the end of the experiment in order to reduce the rate of development and growth of the later harvested catch crops, because all catch crops could not be handled at the same time.

A total of $11 \mathrm{~g} \mathrm{~N}$ and $2.1 \mathrm{~g} \mathrm{P} \mathrm{m}^{-2}$ and sufficient amounts of other necessary elements in a complete nutrient solution were applied in a split dose (one-third before sowing and two-thirds at 4 weeks after sowing). The solution was mixed in $1 \mathrm{~L}$ water and evenly sprayed onto the soil. The catch crops were irrigated with tap water when needed during the whole growing period.

Harvest of the catch crops

In order to carry out measurements on fresh plant materials immediately after harvest and then start the subsequent $\mathrm{P}$ release experiment, only two catch crop 
species were harvested simultaneously, in an order determined by their development stage and size (Table 1). All catch crops were harvested within 1 month. White radish and white mustard were harvested 3 days after start of flowering, phacelia and oilseed radish at start of flowering, red clover and chicory during leaf formation, and ryegrass and cocksfoot during tillering, i.e. after 62 days of growth (Table 1). At harvest, the plant shoots were cut off at the soil surface with a pair of scissors and plant height and fresh weight in each box were recorded. Roots were collected in a 2-mm mesh by washing away the sand carefully with tap water. The collected roots were air-dried for $2 \mathrm{~h}$ at room temperature $\left(20 \pm 2{ }^{\circ} \mathrm{C}\right)$, and weighed. A $20-50 \mathrm{~g}$ sample of fresh shoots and a similar sample of fresh roots were taken from each box for analysis of total-P concentration in the plant materials. Thereafter, all remaining plant materials of each crop (shoots and roots separately) from the three boxes were pooled into one sample in order to eliminate variation between replicates generated in the greenhouse. The pooled samples were subsampled for the subsequent $\mathrm{P}$ release experiment and for measurements of general root features. Red clover had a low germination rate and poor biomass and was therefore excluded from the P release experiment.

Phosphorus release experiment with four extreme components of winter climate

Twelve fresh subsamples ( $\mathrm{g}$ fresh weight per sample) were taken randomly from each pooled species sample

Table 1 Catch crop, crop type, percentage germination, number of growing days and mean height of shoots above the soil surface at harvest

\begin{tabular}{|c|c|c|c|c|}
\hline Catch crop & $\begin{array}{l}\text { Crop } \\
\text { type }\end{array}$ & Germination, $\%$ & $\begin{array}{l}\text { Growing } \\
\text { days }\end{array}$ & $\begin{array}{l}\text { Height, } \\
\mathrm{cm}\end{array}$ \\
\hline White radish & Annual & 66 & 34 & 28 \\
\hline $\begin{array}{l}\text { White } \\
\text { mustard }\end{array}$ & Annual & 92 & 34 & 40 \\
\hline Oilseed radish & Annual & 89 & 47 & 30 \\
\hline Phacelia & Annual & 74 & 47 & 50 \\
\hline Red clover & Perennial & 50 & 54 & 18 \\
\hline Chicory & Perennial & 78 & 54 & 30 \\
\hline $\begin{array}{l}\text { Perennial } \\
\text { ryegrass }\end{array}$ & Perennial & 85 & 62 & 35 \\
\hline Cocksfoot & Perennial & 77 & 62 & 35 \\
\hline
\end{tabular}

and exposed to four treatments ( 3 replicates per treatment) comprising different combinations of freezing and thawing, followed by $\mathrm{P}$ release with water extraction. Since leaves were the dominant constituent of the shoots for all species, only new growing leaves were included in the shoot samples, to eliminate differences between species caused by differences in the proportion of leaves in the samples. The root samples included as much as possible of the complete root; branches and abundant fine roots. Before the freezing-thawing treatments, the $P$ in all subsamples were extracted with $100 \mathrm{~mL}$ distilled water and end-to-end shaking at a rate of $16 \mathrm{rpm}$ for $1 \mathrm{~h}$ at room temperature $\left(20 \pm 2{ }^{\circ} \mathrm{C}\right)$ to determine initial $\mathrm{P}$ release from intact plant material (E0). The water extract samples were filtered through $00 \mathrm{H}$ filter paper (Munktell Filter AB, Falun, Sweden) and stored in glass bottles at $4{ }^{\circ} \mathrm{C}$ before analysis of $\mathrm{P}$.

Three combinations of freezing-thawing treatments were used to simulate some extreme conditions in the Nordic winter climate, plus one treatment without freezing (Table 2). The number of consecutive freezingthawing events in each combination was limited to a maximum of four, based on the results from a pre-test with white radish and white mustard showing that only minor amounts of additional $\mathrm{P}$ were released when freezing-thawing treatments were repeated more than four times.

- Treatment sFTC (one single cycle with longlasting freezing and thawing): Samples were continuously frozen at $-18^{\circ} \mathrm{C}$ for $62 \mathrm{~h}$ and thawed at $+18{ }^{\circ} \mathrm{C}$ for $10 \mathrm{~h}$, followed by four consecutive water extractions after every $5 \mathrm{~h}$.

- Treatment NF (no freezing): Samples were kept at $+4{ }^{\circ} \mathrm{C}$ for $20 \mathrm{~h}$, followed by a single water extraction. This procedure was repeated four times.

- Treatment cFTC (continuous freezing-thawing cycles): Samples were frozen at $-18{ }^{\circ} \mathrm{C}$ for $10 \mathrm{~h}$ and thawed at $+18{ }^{\circ} \mathrm{C}$ for $10 \mathrm{~h}$. The freezingthawing cycle was repeated four times before water extractions were carried out in the same way as for treatment 1.

- Treatment dFTC (discontinuous freezing-thawing cycles): Samples were frozen at $-18{ }^{\circ} \mathrm{C}$ for $10 \mathrm{~h}$ and thawed at $+18{ }^{\circ} \mathrm{C}$ for $10 \mathrm{~h}$, followed by a single water extraction. This procedure was repeated four times. 
Table 2 Combinations of freezing-thawing-extraction events illustrating the different treatments in the P release experiment, and possible components of winter climate that they represent

\begin{tabular}{llll}
\hline Treatment & Treatment explanation & Order of events & Component of winter condition \\
\hline sFTC & $\begin{array}{c}\text { One single cycle with long-lasting } \\
\text { freezing and thawing } \\
\text { No freezing }\end{array}$ & F-F-F-F-F-F-F-F-T-E-E-E-E & $\begin{array}{c}\text { Extreme cold winter followed by one } \\
\text { melting period } \\
\text { Winter without any deep frost }\end{array}$ \\
cFTC & Continuous freezing-thawing cycles & F-T-F-T-F-T-F-T-E-E-E-E & $\begin{array}{c}\text { Several deep frost events but only one final } \\
\text { period with snowmelt/rain }\end{array}$ \\
dFTC & Discontinuous freezing-thawing cycles & F-T-E-F-T-E-F-T-E-F-T-E & $\begin{array}{c}\text { Several deep frost events, each of which is } \\
\text { always followed by snowmelt/rain }\end{array}$ \\
\hline
\end{tabular}

$\# F$ freezing, $T$ thawing, $E$ extraction with water, and $N$ no freezing

Chemical analysis of plant and water and root scanning

The plant samples were dried at $40^{\circ} \mathrm{C}$, analysed for dry matter (DM) content and ground for determining the total-P concentrations which was carried out with Inductive Coupled Plasma analysis (ICP, Perkin Elmer, Wellesley, America) after oxidative digestion of the samples with concentrated nitric acid $\left(\mathrm{HNO}_{3}\right)$. All data are presented on a DM basis unless otherwise stated.

Phosphorus in the water extract (WEP) was determined by spectrophotometer at wavelength $904 \mathrm{~nm}$ according to Murphy and Riley (1962). Dissolved reactive P (DRP) was determined without oxidation of the extracts and total-P after oxidation of the samples with sulphuric acid $\left(\mathrm{H}_{2} \mathrm{SO}_{4}\right)$ and potassium persulphate $\left(\mathrm{K}_{2} \mathrm{~S}_{2} \mathrm{O}_{8}\right)$ according to the International Standards Organization method (ISO 2003).

A 100-170 g sample of fresh roots from each of the eight catch crops tested was scanned with an Epson perfection 4990 PHOTO scanner (Epson America Inc., California, America). The fine roots in each scanning sample were separated from each other to avoid overlapping. The scanner produced a raster image format with resolution 4,800 $\times 9,600$ square pixels dots per inch (dpi). Professional WinRHIZO 2007a software (Régent Instruments, Quebec, Canada) was used to analyse the scanned images and determine root morphology parameters such as length, surface area and volume, which were recalculated to specific values (SRL, SSA and SRV) per unit dry matter.

\section{Statistical analyses}

The SAS software (Version 9.2) was used for statistical analysis. The General Linear Model was used for analysis of differences in plant biomass and $\mathrm{P}$ concentrations in plant materials between the catch crops, and for regressions of root morphology parameters with $\mathrm{P}$ content in the plant and $\mathrm{P}$ release. Differences in $\mathrm{P}$ release from the catch crops were analysed with a Mixed Model for repeated measurements (Littell et al. 2006), where the "repeated" statement was used to realise the repeated extractions on the same sample. A spatial power covariance structure was used to model correlations between measurements over time. The complete model including all the factors (crop sample, crop part, treatment, extraction time) and their interactions was used and WEP concentrations at E0 were included in the model as baseline values. A significance level of $\alpha=0.05$ was used throughout this study unless otherwise stated.

\section{Results}

Harvested biomass, plant total-P and root parameters

At harvest, chicory, phacelia and oilseed radish had significantly more whole plant biomass than white radish, perennial ryegrass, white mustard, cocksfoot or red clover (Table 3). Chicory had the highest root biomass and phacelia and oilseed radish the highest shoot biomass. Red clover had low shoot and root biomass.

The concentration of total-P in the shoots ranged from $0.21 \%$ in perennial ryegrass to $0.35 \%$ in red clover (Table 3 ). In general, annual catch crops had a higher concentration of total-P in the shoots than perennial crops, with the exception of red clover. The concentration of total-P in the roots ranged from $0.08 \%$ in chicory to $0.36 \%$ in red clover. Root 
Table 3 Biomass production and concentration of total-P in the shoots and roots, and total biomass and total-P uptake of the whole plant for the eight catch crops

\begin{tabular}{|c|c|c|c|c|c|c|}
\hline \multirow[t]{2}{*}{ Catch crop } & \multicolumn{2}{|l|}{ Shoot } & \multicolumn{2}{|l|}{ Root } & \multicolumn{2}{|c|}{ Whole plant } \\
\hline & $\begin{array}{l}\text { Biomass, } \\
\mathrm{g} \mathrm{m}^{-2}\end{array}$ & Total-P, \% & $\begin{array}{l}\text { Biomass, } \\
\mathrm{g} \mathrm{m}^{-2}\end{array}$ & Total-P, \% & $\begin{array}{l}\text { Biomass, } \\
\mathrm{g} \mathrm{m}^{-2}\end{array}$ & $\begin{array}{l}\text { Total-P uptake, } \\
\mathrm{g} \mathrm{m}^{-2}\end{array}$ \\
\hline White radish & $340 \mathrm{c}$ & $0.346 \mathrm{c}$ & $110 \mathrm{~b}$ & $0.221 \mathrm{~b}$ & $450 \mathrm{~b}$ & $1.41 \mathrm{~cd}$ \\
\hline White mustard & $300 \mathrm{c}$ & $0.323 \mathrm{bc}$ & $90 \mathrm{~b}$ & $0.184 \mathrm{ab}$ & $390 \mathrm{~b}$ & $1.14 \mathrm{c}$ \\
\hline Oilseed radish & $530 \mathrm{~d}$ & $0.268 \mathrm{~b}$ & $250 \mathrm{~d}$ & $0.133 \mathrm{ab}$ & $780 \mathrm{c}$ & $1.75 \mathrm{e}$ \\
\hline Phacelia & $530 \mathrm{~d}$ & $0.259 \mathrm{ab}$ & $310 \mathrm{e}$ & $0.088 \mathrm{a}$ & $840 \mathrm{c}$ & $1.64 \mathrm{de}$ \\
\hline Red clover & $90 \mathrm{a}$ & $0.349 \mathrm{c}$ & $40 \mathrm{a}$ & $0.355 \mathrm{c}$ & $130 \mathrm{a}$ & $0.44 \mathrm{a}$ \\
\hline Chicory & $360 \mathrm{c}$ & $0.235 \mathrm{ab}$ & $480 \mathrm{f}$ & $0.083 \mathrm{a}$ & $840 \mathrm{c}$ & $1.24 \mathrm{c}$ \\
\hline Perennial ryegrass & $190 \mathrm{~b}$ & $0.207 \mathrm{a}$ & $230 \mathrm{~cd}$ & $0.168 \mathrm{ab}$ & $420 \mathrm{~b}$ & $0.77 \mathrm{~b}$ \\
\hline Cocksfoot & $180 \mathrm{~b}$ & $0.224 \mathrm{ab}$ & $190 \mathrm{c}$ & $0.126 \mathrm{ab}$ & $370 \mathrm{~b}$ & $0.64 \mathrm{ab}$ \\
\hline
\end{tabular}

Different letters (a, b, c, d, e, f) within columns indicate significant differences $(\alpha=0.05, n=3)$

total-P concentration did not differ significantly between annual and perennial crops or between species with fibrous roots and species with taproots. However, root total-P concentrations increased significantly with increasing SRL, SSA and SRV for the five species with taproots. As a mean, the roots contained $24 \%$ of total-P in the plant tissues.

There were no clear differences in SRL, SSA and SRV between non-grass species with taproots and extensive fine roots and grass species with only fibrous roots (Table 4). However, the non-grass species had a similar root surface area to volume ratio, around $100 \mathrm{~cm}^{-1}$, whereas perennial ryegrass and cocksfoot had a higher ratio, 120 and $147 \mathrm{~cm}^{-1}$, respectively. All the non-grass species except red clover took up more P than the grasses. Although red clover had the highest SRL, SSA and SRV among all the species, it had the lowest $\mathrm{P}$ uptake due to its low biomass production.
Oilseed radish and phacelia had the highest $\mathrm{P}$ uptake and most of it was present in the shoots.

Phosphorus release from catch crops in water extraction

The WEP concentrations (g P kg ${ }^{-1} \mathrm{DM}$ ) differed significantly between catch crop species, crop parts (shoots and roots), different freezing or no freezing treatments, extraction sequences, and all interactions of these (Table 5).

Phosphorus release from shoots None of the species released much $\mathrm{P}$ in the NF treatment, but on average over all treatments, the shoots of the two radish species and white mustard released significantly more $\mathrm{P}$ than the other species (Table 6). However, oilseed radish released less $\mathrm{P}$ than the other two Brassicas
Table 4 Root morphological properties of the eight catch crops, including root type, specific root length (SRL), specific root surface area (SSA), specific root volume (SRV), and ratio of SSA to SRV (SSA/SRV)

\begin{tabular}{llllcc}
\hline Catch crop & Root type & $\begin{array}{l}\text { SRL, } \\
\mathrm{m} \mathrm{g}^{-1}\end{array}$ & $\begin{array}{l}\text { SSA, } \\
\mathrm{dm}^{2} \mathrm{~g}^{-1}\end{array}$ & $\begin{array}{l}\text { SRV, } \\
\mathrm{cm}^{3} \mathrm{~g}^{-1}\end{array}$ & $\begin{array}{l}\text { SSA/SRV, } \\
\mathrm{cm}^{-1}\end{array}$ \\
\hline White radish & Fleshy taproot & 58 & 7.2 & 7.1 & 101 \\
White mustard & Shallow taproot & 35 & 4.5 & 4.8 & 94 \\
Oilseed radish & Fleshy taproot & 25 & 3.2 & 3.2 & 100 \\
Phacelia & Extensive, fine roots & 49 & 5.9 & 5.8 & 102 \\
Red clover & Thin, deep taproot & 85 & 10.7 & 10.9 & 98 \\
Chicory & Thick, stout taproot & 21 & 2.4 & 2.3 & 104 \\
Perennial ryegrass & Fibrous roots & 52 & 5.5 & 4.6 & 120 \\
Cocksfoot & Fibrous roots & 62 & 5.3 & 3.6 & 147 \\
\hline
\end{tabular}


Table 5 Mixed Model analysis on the effects of different factors and factor interactions on WEP ( $\left.\mathrm{g} \mathrm{P} \mathrm{kg}^{-1} \mathrm{DM}\right)$ from the plant materials. The factors include catch crop sample (C); crop part $(\mathrm{P})$, i.e. shoot or root; freezing-thawing treatment $(\mathrm{T})$; and extraction $(\mathrm{E})$

\begin{tabular}{|c|c|c|c|c|}
\hline Factor/Interaction & Num $D_{F}^{\#}$ & Den $\mathrm{DF}^{\S}$ & F value & $\operatorname{Pr}>F^{a}$ \\
\hline $\mathrm{C}$ & 6 & 112 & 303 & $<.0001$ \\
\hline $\mathrm{P}$ & 1 & 112 & 423 & $<.0001$ \\
\hline $\mathrm{T}$ & 3 & 112 & 535 & $<.0001$ \\
\hline $\mathrm{E}$ & 4 & 448 & 2471 & $<.0001$ \\
\hline $\mathrm{C} * \mathrm{P}$ & 6 & 112 & 54 & $<.0001$ \\
\hline $\mathrm{C}^{*} \mathrm{~T}$ & 18 & 112 & 32 & $<.0001$ \\
\hline $\mathrm{C}^{*} \mathrm{E}$ & 24 & 448 & 179 & $<.0001$ \\
\hline $\mathrm{P} * \mathrm{~T}$ & 3 & 112 & 78 & $<.0001$ \\
\hline $\mathrm{P}^{*} \mathrm{E}$ & 4 & 448 & 79 & $<.0001$ \\
\hline $\mathrm{T}^{*} \mathrm{E}$ & 12 & 448 & 321 & $<.0001$ \\
\hline $\mathrm{C} * \mathrm{P} * \mathrm{~T}$ & 18 & 112 & 9 & $<.0001$ \\
\hline $\mathrm{C} * \mathrm{P} * \mathrm{E}$ & 24 & 448 & 34 & $<.0001$ \\
\hline $\mathrm{C} * \mathrm{~T}^{*} \mathrm{E}$ & 72 & 448 & 25 & $<.0001$ \\
\hline $\mathrm{P} * \mathrm{~T} * \mathrm{E}$ & 12 & 448 & 31 & $<.0001$ \\
\hline $\mathrm{C}^{*} \mathrm{P} * \mathrm{~T} * \mathrm{E}$ & 72 & 448 & 7 & $<.0001$ \\
\hline
\end{tabular}

\#Num DF: number of degrees of freedom in the model

$\S$ Den DF: number of degrees of freedom associated with the model errors

qF value: the $\mathrm{F}$ statistic for the given predictor and test statistic $a \operatorname{Pr}>\mathrm{F}$ : the p-value associated with the $\mathrm{F}$ statistic of a given effect and test statistic.

and about as little $\mathrm{P}$ as chicory, phacelia, ryegrass and cocksfoot in the sFTC treatment, and as chicory in the dFTC treatment, where the smallest release was from the grasses.

Total-P release from the shoots after freezingthawing was significantly higher than that with no freezing for all species. The release from the repeated FTCs also tended to be higher than after one single, long-lasting FTC. The general ranking of total-P release was $\mathrm{cFTC}=\mathrm{dFTC}>\mathrm{sFTC}>\mathrm{NF}$, but it varied to some extent with species (Table 6). The shoots of white mustard, oilseed radish, phacelia, perennial ryegrass and cocksfoot lost more P in the cFTC treatment, while those of white radish and chicory lost more $\mathrm{P}$ in the dFTC treatment. However, all the species had the smallest release of $\mathrm{P}$ from the NF treatment, which was only $0-3 \%$ of the WEP in the other treatments.

The WEP concentrations differed significantly with the number of extractions in all three treatments with freezing-thawing (dFTC, cFTC and sFTC) and were highest at the first extraction after freezing (E1; Fig. 1a, c, d). Thereafter, the WEP concentration decreased continuously until the fourth extraction, at which it was still slightly higher than the baseline values (E0). At E1, the cFTC treatment had higher WEP concentration than the other treatments. For the NF treatment, the WEP concentration did not differ significantly with extraction number and was even lower than the baseline values (Fig. 1b).

Phosphorus release from roots The patterns of $\mathrm{P}$ release from the roots differed from those for the shoots in some aspects. First of all, the roots released significantly less $\mathrm{P}$ after freezing-thawing than the shoots for all species tested except the two grasses (Table 6). On average, the roots of all species samples released $43 \%$ less total-P than the shoots. All the freezing treatments resulted in significantly higher WEP from roots than the NF treatment, which was similar to the pattern of release from the shoots. However, the differences between the three treatment combinations for the roots were minor and not significant, and the ranking was the same for the roots of all species: $\mathrm{sFTC}=\mathrm{dFTC}=\mathrm{cFTC}>\mathrm{NF}($ Table 6$)$.

Phosphorus release from the root samples (Table 6) decreased in the order white radish $>$ white mustard $>$ oilseed radish $=$ perennial ryegrass $=$ cocksfoot $>$ phacelia $=$ chicory, on average for all $\mathrm{P}$ release measurements. With repeated extraction without freezing (NF treatment), white mustard released more $\mathrm{P}$ than white radish. For this treatment, the WEP concentration decreased rapidly for a few species, but usually slowly from the first to the last extraction (Fig. 2b).

After freezing-thawing, WEP in the roots of all species decreased significantly with extraction number (Fig. 2a, c, d), with an even more rapid decrease rate than in the shoots. The WEP concentration decreased to the baseline value after three extractions (E1, E2 and E3) and the concentration at E4 was significantly lower than the baseline value. This indicated that all $\mathrm{P}$ in the plant tissue with the potential for release had been extracted within three consecutive extractions.

Phosphorus release from the whole plant Almost all the $\mathrm{P}$ in both shoots and roots of the catch crops was released to water after a few FTCs and extractions. When the shoots and the roots were considered 


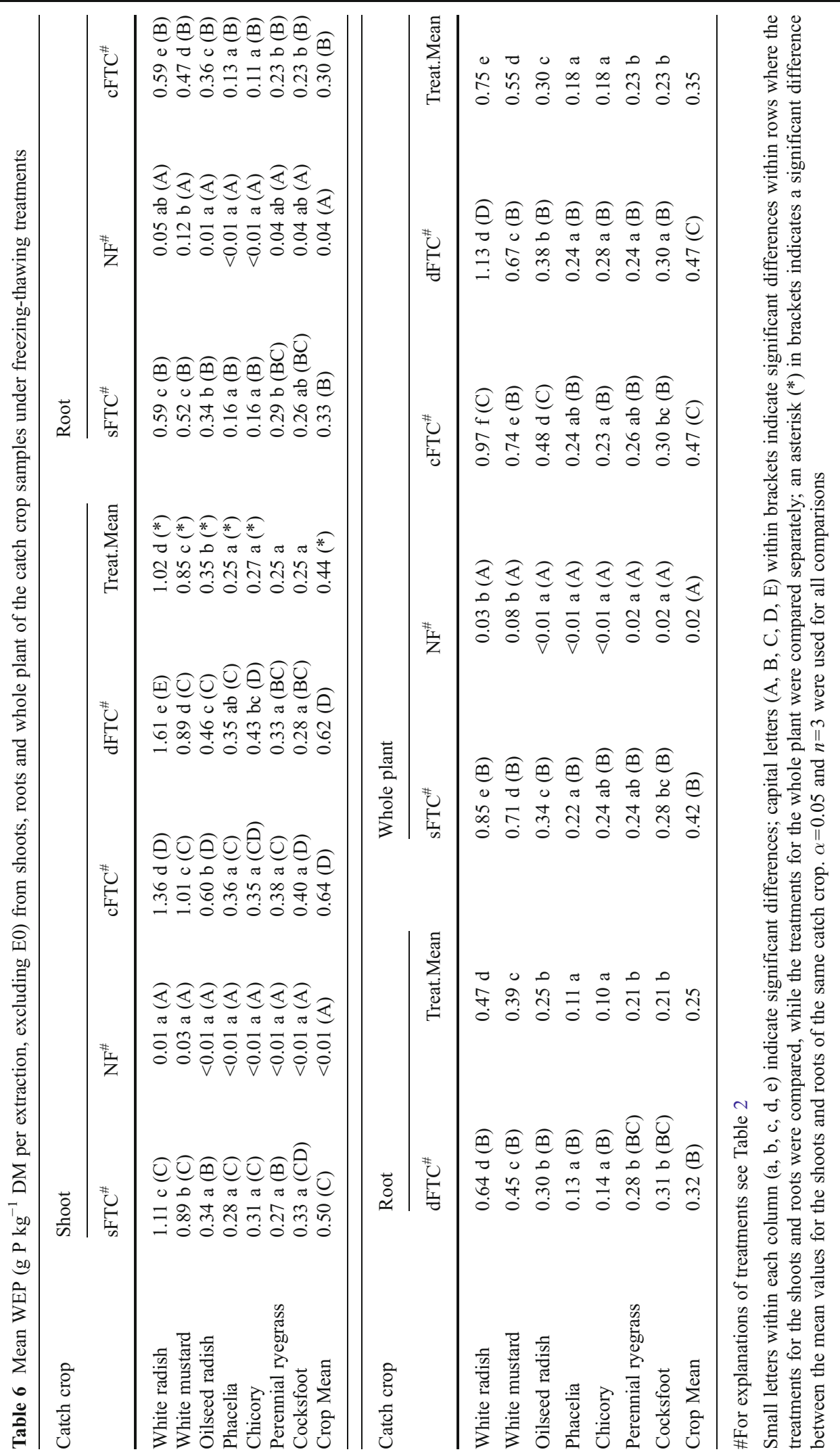


Fig. 1 Concentrations of WEP in shoots of catch crops at five consecutive extractions (E0-E4) under different freezing-thawing cycles or no freezing. WR white radish, $W M$ white mustard, $O R$ oilseed radish, $\mathrm{PH}$ phacelia, $\mathrm{CH}$ chicory, $P R$ perennial ryegrass, and $C O$ cocksfoot; $L S D$ least significant difference. For explanation of treatments see Table 2. Note different scale of Y-axis in $\mathbf{b}$
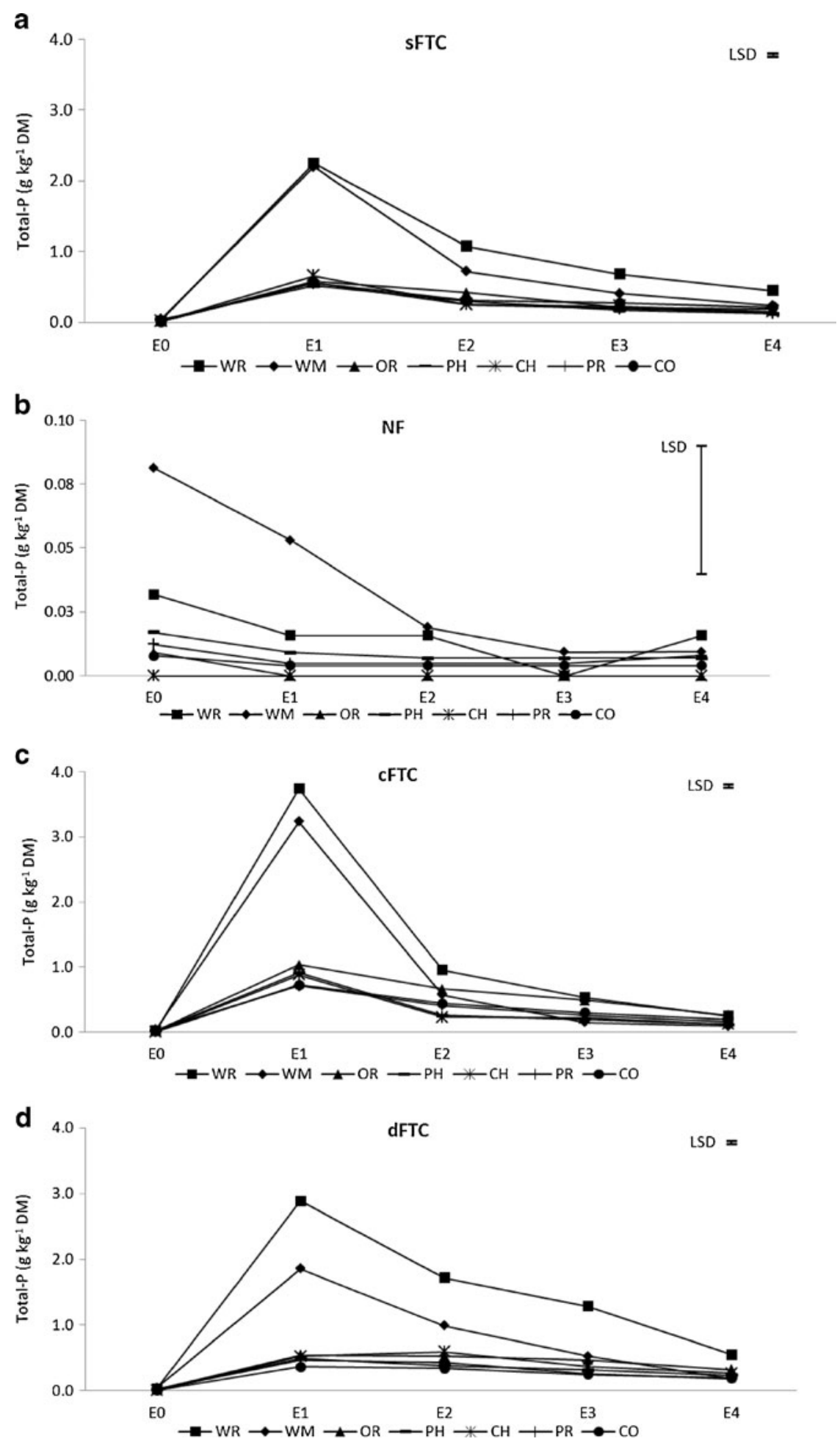

together and as an average for all four treatments, total-P release from the whole plant for the species samples was in the order: white radish $>$ white mustard $>$ oilseed radish $>$ perennial ryegrass $=$ cocksfoot $>$ chicory $=$ phacelia (Table 6 ). The ranking differed with different treatments, but in general, 
Fig. 2 Concentrations of WEP in roots of catch crops at five consecutive extractions (E0-E4) under different freezing-thawing cycles or no freezing. WR white radish, $W M$ white mustard, $O R$ oilseed radish, $P H$ phacelia, $C H$ chicory, $P R$ perennial ryegrass and $C O$ cocksfoot; $L S D$ least significant difference. For explanation of treatments see Table 2. Note different scale of Y-axis in $\mathbf{b}$ a

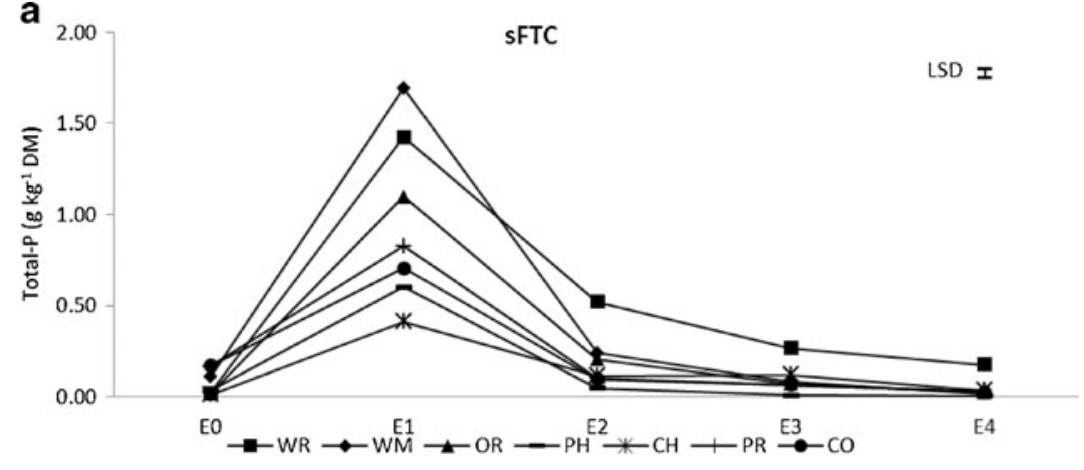

b
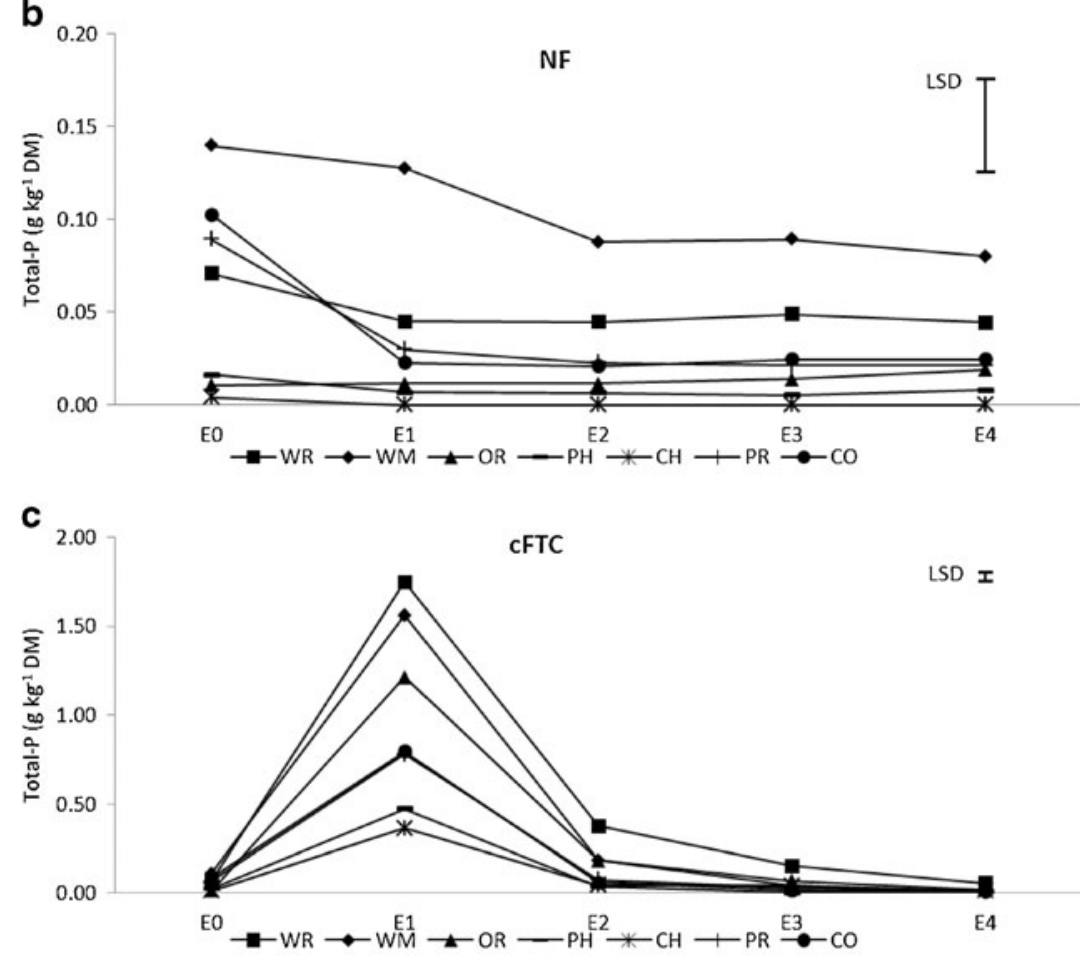

d

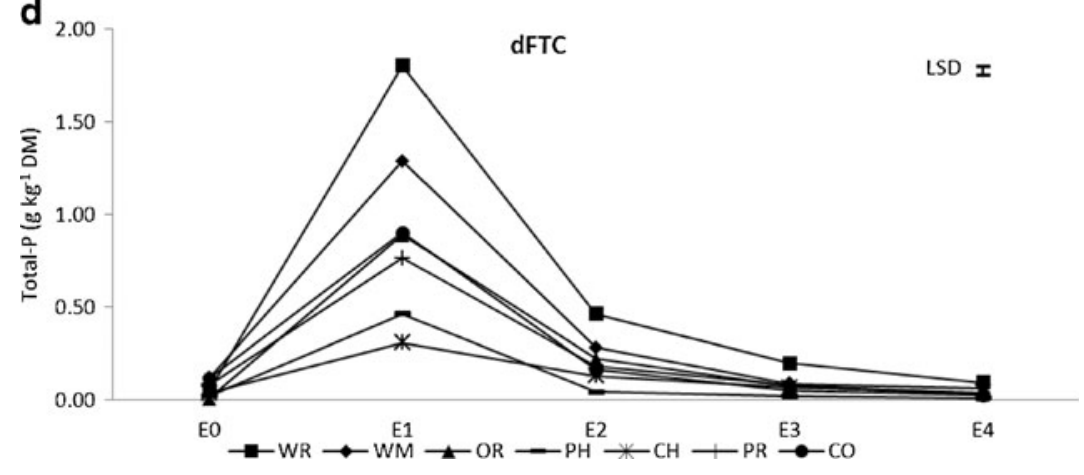

oilseed radish, white radish and white mustard had significantly higher WEP concentrations than the other catch crops.
The treatment ranking based on the mean total-P release from the seven crop species included in this part of the experiment was: $\mathrm{cFTC}=\mathrm{dFTC}>\mathrm{sFTC}>\mathrm{NF}$ 
(Table 6). Freezing-thawing significantly increased the release of $\mathrm{P}$ from all species compared with no freezing, and repeated FTCs significantly increased P release from the two radish species compared with a single FTC. White radish released most $\mathrm{P}$ in $\mathrm{dFTC}$, while oilseed radish released most in cFTC.

The major form of P in the total WEP was DRP (up to $100 \%$ for the shoots and up to $96 \%$ for the roots) (Table 7), which is the most bio-available form of P. In general, the proportion of DRP was lowest for the NF treatment. The proportion of DRP in the roots was slightly lower than that for the shoots in the three freezing-thawing treatments. Non-grass species samples had higher proportions of DRP than the two grass species, which was most obvious for the shoots.

WEP release in relation to plant $\mathrm{P}$ concentration and root morphological properties

In the freezing-thawing treatments, cumulative WEP after five extractions (including E0) was significantly correlated with $\mathrm{P}$ concentration in the shoots and that in the roots. Cumulative $\mathrm{P}$ release increased with increasing concentration of $\mathrm{P}$ in different species. This is exemplified for the dFTC treatment in Fig. 3 (shoots: $p=0.006$; roots: $p=0.002$ ). No corresponding correlation was found for the NF treatment. In addition, the cumulative $\mathrm{P}$ release was strongly correlated to root morphological properties. This was most evident for specific root surface area (Fig. 4), which was also significantly correlated to concentration of total-P in the taproot $(p=0.03)$.

\section{Discussion}

Phosphorus release in relation to catch crop species and plant part

The results showed that all the $\mathrm{P}$ in catch crop plant tissues can potentially be released to water after severe freezing $\left(-18^{\circ} \mathrm{C}\right)$. The potential $\mathrm{P}$ release from both shoots and roots was strongly correlated to total-P concentration in the respective plant parts. However, the potential $\mathrm{P}$ release, especially from shoots, was possibly overestimated, since the shoot samples included only young leaves, which commonly have higher $\mathrm{P}$ concentrations than other shoot parts (Aerts and Chapin 1999). This is probably the reason why the estimated cumulative release of $\mathrm{P}$ even exceeded the total-P content in the plant materials in some cases.

The box samples were pooled before the $\mathrm{P}$ release experiment in order to reduce variations caused by the environment in the greenhouse and obtain a clear estimate of the variation in the effect of freezing-thawing on $P$ release. However, it also meant that we were unable to use the variation obtained in the greenhouse to estimate differences between species. Nevertheless, the variation among the subsamples can be used to identify differences in the amount of $\mathrm{P}$ released among the representative samples of the plant materials produced.

Phosphorus release after freezing-thawing was higher from the shoots and roots of annual crops than from those of perennial crops. The only exception was phacelia, which did not release more $\mathrm{P}$ than the perennial crops. The higher release from annual crops may

Table 7 Proportion (\%) of dissolved reactive P in total WEP

\begin{tabular}{|c|c|c|c|c|c|c|c|c|}
\hline \multirow[t]{2}{*}{ Catch crop } & \multicolumn{4}{|l|}{ Shoot } & \multicolumn{4}{|l|}{ Root } \\
\hline & $\mathrm{sFTC}^{\#}$ & $\mathrm{NF}^{\#}$ & $\mathrm{cFTC}^{\#}$ & $\mathrm{dFTC}^{\#}$ & $\mathrm{sFTC}^{\#}$ & $\mathrm{NF}^{\#}$ & $\mathrm{cFTC}^{\#}$ & $\mathrm{dFTC}^{\#}$ \\
\hline White radish & 99 & 36 & 94 & 66 & 96 & 65 & 88 & 79 \\
\hline White mustard & 96 & 73 & 100 & 87 & 88 & 89 & 77 & 85 \\
\hline Oilseed radish & 95 & 60 & 95 & 93 & 92 & 51 & 93 & 88 \\
\hline Phacelia & 93 & 86 & 95 & 93 & 85 & 74 & 85 & 76 \\
\hline Chicory & 93 & $-a$ & 89 & 91 & 80 & $-a$ & 77 & 64 \\
\hline Perennial ryegrass & 78 & 53 & 75 & 80 & 74 & 74 & 69 & 80 \\
\hline Cocksfoot & 89 & 44 & 82 & 87 & 68 & 86 & 69 & 77 \\
\hline
\end{tabular}

\#For explanation of treatments see Table 2

aTotal WEP $=0$ 
Fig. 3 Correlations between cumulative WEP after five extractions (including E0) in the dFTC treatment and concentrations of total-P in the shoots and the roots of the catch crops $(n=7)$

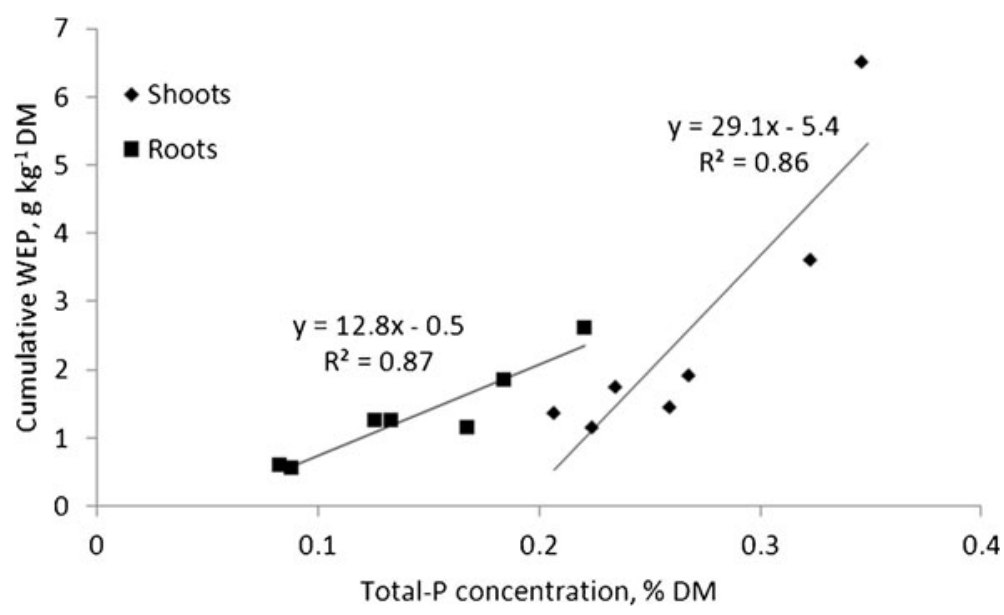

be due to higher total-P concentration in the tissues than for the perennial species, which is supported by results from a laboratory leaching study by Miller et al. (1994). They observed that about $30 \%$ of the $\mathrm{P}$ in the shoots of oilseed radish and annual ryegrass was leached after freezing (alone or in combination with drying), but only about $20 \%$ of the $\mathrm{P}$ in the perennial species red clover. In a field study, De Baets et al. (2011) observed that the roots of annual white mustard, oilseed radish, phacelia and oats (Avena sativa L.) were all more vulnerable to frost than the finebranched root systems of perennial ryegrass and rye (Secale cereal L.). Phacelia and chicory had the lowest release of $\mathrm{P}$ from both shoots and roots after freezing of the crops included in the present study. The positive results for phacelia are surprising, since Hansen et al. (2000) reported that this species is a frost-sensitive catch crop that releases large amounts of $\mathrm{N}$ after frost damage. Although the measured $\mathrm{P}$ release from the roots of phacelia was low due to low root $\mathrm{P}$ concentrations in the present study, we observed that they were very fragile and easy to break, and thus it was likely that part of $\mathrm{P}$ in the roots had already been lost during root collection by washing with water. In addition, the water extract from roots of phacelia after freezing-thawing was darker than the extracts from the other species, probably as a result of effluence of cell constituents after cell burst, which may indicate more severe frost damage than in the other species. In contrast, chicory is an indigenous species in Scandinavia and its roots are stout and reported to be resistant to frost (Neefs et al. 2000), as is the whole plant (Skinner and Gustine 2002). In addition, the proportion of DRP in total-P in both shoots and roots of chicory was lower than that in shoots and roots of phacelia. Therefore, chicory seems to be the most promising species as a $\mathrm{P}$ catch crop among the here seven species tested in our P release experiment.

The annual catch crops grew faster and reached the flowering stage earlier than the perennial species in our greenhouse experiment. However, growth and dry
Fig. 4 Correlations between concentration of total-P in the roots and specific root surface area (SSA) for the catch crops with taproots $(n=5)$; and between cumulative WEP after five extractions (including E0) in the dFTC treatment and SSA for the catch crops with taproots $(n=4)$

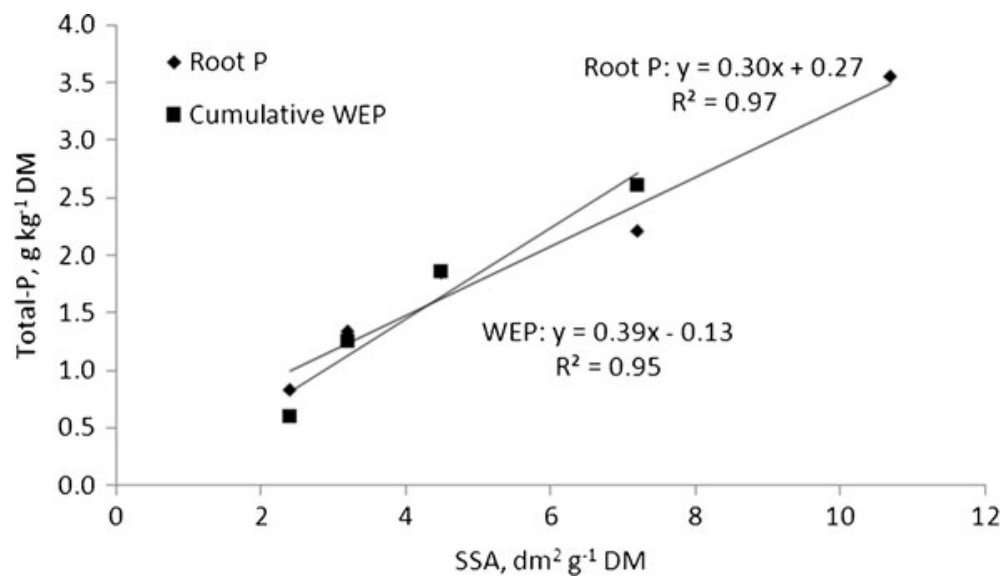


matter production of shoots and roots are highly dependent on growing conditions and results from greenhouse experiments cannot be directly generalised and translated to field conditions. The amount of harvested root biomass in the present study was higher than reported in some field experiments and lower than in others. For instance, topsoil root biomass of oilseed radish and phacelia was greater than that reported by Thorup-Kristensen (2001) after 3.5 months of growth in the field (despite similar shoot biomass), but the topsoil root biomass of white mustard, perennial ryegrass, oilseed radish and phacelia was lower than that reported by De Baets et al. (2011) after 4 months of growth in the field. In contrast, the shoot biomass of perennial ryegrass and cocksfoot was similar to that observed for years with satisfactory weather conditions in field experiments where the grasses were insown in a barley crop and collected 80 day after harvest of the barley (Liu et al. unpublished observations). In addition, the concentrations of total-P in the shoots of all eight catch crops $(0.21-0.35 \%)$ were similar to those in the same field study by Liu et al. $(0.27 \%-$ $0.46 \%$, unpublished observations). Consequently, the results may be used for relative comparisons between crop samples.

Another debatable point when comparing catch crop samples was that the crops were harvested at different temperatures after different periods of growth, which probably affected dry matter production, plant $\mathrm{P}$ concentration and also possibly release of $\mathrm{P}$ to some extent. However, the two crop species that were simultaneously harvested, white radish and white mustard, demonstrated significant differences in release of P. Moreover, all crops were harvested according to their rate of development, i.e. annual species followed by perennial species, which is logical in relation to field conditions.

Based on the present study, shoots seem to be the primary contributor to $\mathrm{P}$ losses from catch crops after frost, with significantly higher release of $\mathrm{P}$ than from the roots. The aboveground parts of the plant are directly exposed to cold air on many occasions during winter, particularly when there is no snow cover. They are therefore more likely to experience more frequent FTCs than the roots. However, the contribution of roots to P losses should be considered too, since as long as the roots are living, plants are more likely to recapture lost $\mathrm{P}$. In addition, the roots represent a significant proportion of the $\mathrm{P}$ in the whole plant.
There was no clear pattern of difference in WEP between species with a taproot and those with fibrous roots. However, the fleshy taproot tended to release more $\mathrm{P}$ than non-fleshy roots. For the four taproot species used in the $\mathrm{P}$ release experiment, release of total-P increased with increasing specific root length, specific surface area and specific volume, which were consistent. Fleshy taproots with a higher morphological index may take up P more easily from soil and store more $\mathrm{P}$ in the roots than fibrous roots. Correspondingly, fleshy taproots can be expected to release more P after frost. For the same unit of root biomass, the root length, surface area and volume of white radish were all more than twice those of oilseed radish. This indicates faster root growth and stronger penetrating ability of white radish as demonstrated by Chen and Weil (2010) and also results in much higher potential release of $\mathrm{P}$ after frost from white radish than from oilseed radish. The fibrous roots of the two grasses tested, perennial ryegrass and cocksfoot, had the same release of $\mathrm{P}$, which was consistent with the fact that they had similar surface area, even though they differed in length and volume by 20-30\%. Root morphological properties of catch crops, on which knowledge is generally lacking, should therefore be studied in more detail in connection with $\mathrm{P}$ release.

Phosphorus release in relation to different combinations of freezing-thawing treatments

Freezing-thawing treatments significantly increased $\mathrm{P}$ release from the shoots of the catch crops, on average by 40 -to 50 -fold compared with the treatment without freezing, in which the WEP concentrations were in general very low. This is a strong indication that catch crops in regions with extremely cold winters may contribute substantially to $\mathrm{P}$ losses from agricultural fields. Despite the fact that catch crops may release much of their P during a single FTC with extreme temperatures followed by a few extractions, as shown in this study, potential P losses would still increase to some extent with increasing numbers of FTCs. Here, release of $\mathrm{P}$ from the treatments with repeated FTCs (cFTC and dFTC) was higher than that from the treatment with a single FTC (sFTC) for the shoots, but not for the roots. Bechmann et al. (2005) also observed that WEP in shoot biomass of annual ryegrass increased logarithmically with increasing number of FTCs. They attributed this to variations in the 
physiology of plant cells, with only some cells bursting in the first freezing event and additional plant cells being disrupted by the next freezing event. As previously discussed, there was no difference in WEP between cFTC and dFTC for the shoots of white mustard, phacelia, chicory and perennial ryegrass. This indicates that an increase in rainfall or snowmelt during FTCs in winter would not be likely to affect overall potential $P$ losses from these species. In contrast, in our laboratory experiments, shoots from white radish proved to be more sensitive to FTCs under wet conditions, while oilseed radish, with its shorter taproot than white radish, and the grass cocksfoot were more sensitive under dry conditions.

The sensitivity of plants to frost damage may also vary over time in different parts of the plant. The WEP in the roots in the NF treatment was relatively higher than in the shoots in the same treatment. In addition, most of the $\mathrm{P}$ in the roots of the catch crops was released at the first freezing-thawing cycle and very little in the following cycles. This indicates that the roots were more prone to release $\mathrm{P}$ than the shoots under the same freezing conditions in our study. Stier et al. (2003) also demonstrated that the roots of perennial ryegrass and supina bluegrass (Poa supina Schrad.) started freezing more quickly than the shoots under the same temperature. Kleyling et al. (2012) studied frost damage to the roots of velvet-grass (Holcus lanatus) and heather (Calluna vulgaris) caused by different combination of FTC treatments with soil temperature ranging between -10 and $\sim+5{ }^{\circ} \mathrm{C}$. As in the present study, they found that soil FTCs increased root injury, in terms of visible root tissue damage and electrolyte leakage, of the two plant species, but with no difference in root injury between different treatments except for one on velvet-grass.

Harvest of plants is recommended in buffer zones to reduce the risk of $\mathrm{P}$ leaching after frost (UusiKämpä 2005; Räty et al. 2010). However, harvesting alone may not solve all the problems with the risk of $\mathrm{P}$ leaching, since plant roots remain after harvest. While soil and snow cover may protect the roots from frost damage in winter, $\mathrm{P}$ losses from the roots cannot be neglected, especially under extreme weather conditions. Therefore selection of appropriate plant species, especially with roots resistant to frost, is needed. In the context of climate change, it should be borne in mind that plant resistance to frost damage can be improved by modifying factors regulating acclimation (Thomashow 1999). It should also be borne in mind that in greenhouse studies, the crops are not prepared for natural winter conditions and complementary studies on field-grown catch crops are therefore needed.

\section{Conclusions}

After severe frost events, catch crops were shown to release considerable amounts of $\mathrm{P}$ that could be extracted with water. Release of P, especially from the plant shoots, increased with increasing number of freezing-thawing cycles, each followed by water extraction. Such repeated events seemed to cause more P release than one long freezing period. The shoots were the primary contributor of P losses after frost. However, potential P losses from roots under extreme cold and wet weather conditions cannot be neglected. The perennial species tested here (perennial ryegrass, cocksfoot, chicory) had lower potential $\mathrm{P}$ losses than the annual species (white mustard, phacelia, white radish, oilseed radish). For the species with taproots, potential $P$ release increased with increasing specific root length, specific surface area and specific volume. Chicory may be the best catch crop for $\mathrm{P}$ among the species tested, mainly because the root is resistant to frost. Compared with other annual species, phacelia seemed to be a promising catch crop. In contrast, the fast growth and high $\mathrm{P}$ uptake of radish may be a disadvantage with regard to $\mathrm{P}$ release after frost. However, other aspects, e.g. the interaction between the $\mathrm{P}$ released and the soil matrix, should be considered regarding the efficiency of different crops in retaining $\mathrm{P}$ in winter.

Acknowledgments We greatly thank Carl Åkerberg, Department of Crop Production Ecology, Swedish University of Agricultural Sciences (SLU), for assistance in the greenhouse experiment, Iris Dahlin, Department of Ecology, SLU, for assistance in root scanning, Stefan Ekberg and Linnéa Hedlöf Ekvall, Department of Soil and Environment, SLU, for supporting water analysis, and Prof. Ulf Olsson, Department of Economics, SLU, for statistical advice.

Open Access This article is distributed under the terms of the Creative Commons Attribution License which permits any use, distribution, and reproduction in any medium, provided the original author(s) and the source are credited.

\section{References}

Aerts R, Chapin FS III (1999) The mineral nutrition of wild plants revisited: a re-evaluation of processes and patterns. Adv Ecol Res 30(C):1-67 
Aronsson H, Torstensson G (1998) Measured and simulated availability and leaching of nitrogen associated with frequent use of catch crops. Soil Use Manage 14:6-13

Bechmann ME, Kleinman PJA, Sharpley AN, Saporito LS (2005) Freeze-thaw effects on phosphorus loss in runoff from manured and catch-cropped soils. J Environ Qual 34:2301-2309

Brandt M, Ejhed H, Rapp L (2008) Nutrient loading to the Baltic Sea and the Swedish West Coast 2006. Sweden's contribution to HELCOM.s Pollution Load Compilation. Swedish Environment Protection Agency Report 5815

Chen G, Weil RR (2010) Penetration of cover crop roots through compacted soils. Plant Soil 331:31-43

De Baets S, Poesen J, Meersmans J, Serlet L (2011) Cover crops and their erosion-reducing effects during concentrated flow erosion. Catena 85:237-244

Eichler-Löbermann B, Köhne S, Kowalski B, Schnug E (2008) Effect of catch cropping on phosphorus bioavailability in comparison to organic and inorganic fertilization. J Plant Nutr 31(4):659-676

Gilbert L (2003) Phacelia tanacetifolia: what we know about its suitability as an insectary plant and cover crop in the MidAtlantic region. Small Farm Success Project - Fact Sheet Number 2. 12 p. Sustainable Agricultural Systems Lab, USDA, Beltsville, Maryland

Hansen EM, Thomsen IK, Djurhuus J, Kyllingsbæk A, Jørgensen V, Thorup-Kristensen K (2000) Efteraftrøder: Dyrkning, kvælstofoptagelse, Kvælstofudvaskning og eftervirkning. Danmarks JordbrugsForskning (DJF) rapport Markbrug nr 37. In Danish

Henry HAL (2008) Climate change and soil freezing dynamics: historical trends and projected changes. Clim Chang 87:421434

ISO 15681-1 (2003) Water quality- Determination of phosphate and total phosphorus by flow analysis (CFA and FIA). Part 1: method by flow injection analysis (FIA). International Standard Organization

Jones HG (1992) Plants and microclimate, 2nd edn. Cambridge University Press, Cambridge

Kreyling J, Henry HAL (2011) Vanishing winters - trends in soil frost dynamics and snow cover in Germany and their ecological implications. Clim Res 46:269-276

Kreyling J, Peršoh D, Werner S, Benzenberg M, Wöllecke J (2012) Short-term impacts of soil freeze-thaw cycles on roots and root-associated fungi of Holcus lanatus and Calluna vulgaris. Plant Soil 353:19-31

Littell RC, Milliken GA, Stroup WW, Wolfinger RD, Schabenberger O (2006) SAS for mixed models, 2nd edn. SAS Institute Inc., Cary

Mellander P, Löfvenius MO, Laudon H (2007) Climate change impact on snow and soil temperature in boreal Scots pine stands. Clim Chang 85:179-193

Miller MH, Beauchamp EG, Lauzon JD (1994) Leaching of nitrogen and phosphorus from the biomass of three cover crop species. J Environ Qual 23:267-272

Morgan RPC (2005) Soil erosion and conservation, 3rd edn. Blackwell Science Ltd, Oxford
Murphy J, Riley JP (1962) A modified single solution method for the determination of phosphate in natural waters. Anal Chim Acta 27:31-36

Neefs V, Leuridan S, Van Stallen N, De Meulemeester M, De Proft MP (2000) Frost sensitiveness of chicory roots (Cichorium intybus L.). Sci Hortic-Amsterdam 86:185195

Räty M, Uusi-Kämppä J, Yli-Halla M, Rasa K, Pietola L (2010) Phosphorus and nitrogen cycles in the vegetation of differently managed buffer zones. Nutr Cycl Agroecosyst 86:121-132

Roberson T, Bundy LG, Andraski TW (2007) Freezing and drying effects on potential plant contributions to phosphorus in runoff. J Environ Qual 36:532-539

Rummukainen M (2012) Changes in climate and weather extremes in the 21st century. Wires Clim Chang 3(2):115-129

Skinner RH, Gustine DL (2002) Freezing tolerance of chicory and narrow-leaf plantain. Crop Sci 42:2038-2043

Stier JC, Filiault DL, Wisniewski M, Palta JP (2003) Visualization of freezing progression in turfgrasses using infrared video thermography. Crop Sci 43:415-420

Stivers-Young L (1998) Growth, nitrogen accumulation, and weed suppression by fall cover crops following early harvest of vegetables. Hortscience 33(1):60-63

Sturite I, Henriksen TM, Breland TA (2007) Winter losses of nitrogen and phosphorus from Italian ryegrass, meadow fescue and white clover in a northern temperate climate. Agr Ecosyst Environ 120:280-290

Swedish Board of Agriculture (2012) Conditions for environmental subsidizes. www.jordbruksverket/amnesomraden/ stod/miljoersattningar/minskatkbabelackage/vilkor Accessed 2012-06-05. In Swedish

Thomashow MF (1999) Plant cold acclimation: freezing tolerance genes and regulatory mechanisms. Annu Rev Plant Phys 50:571-599

Thorup-Kristensen K (2001) Are differences in root growth of nitrogen catch crops important for their ability to reduce soil nitrate-N content, and how can this be measured? Plant Soil 230:185-195

Timmons DR, Holt RF, Latterell JJ (1970) Leaching of crop residues as a source of nutrients in surface runoff water. Water Resour Res 6(5):1367-1375

Uhlen G (1989) Surface runoff losses of phosphorus and other nutrient elements from fertilized grassland. Norweg J Agr Sci 3:47-55

Ulén B (1997) Nutrient losses by surface run-off from soils with winter cover crops and spring-ploughed soils in the south of Sweden. Soil Till Res 44:165-177

Ulén B, Bechmann M, Fölster J, Jarvie HP, Tunney H (2007) Agriculture as a phosphorus source for eutrophication in the north-west European countries, Norway, Sweden, United Kingdom and Ireland: a review. Soil Use Manage 23(suppl 1):5-15

Uusi-Kämppä J (2005) Phosphorus purification in buffer zones in cold climates. Ecol Eng 24:491-502

White EM (1973) Water leachable nutrients from frozen or dried prairie vegetation. J Environ Qual 2:104-107 